Section Editor

Mitchell S.V. Elkind,

MD, MS

Keon-Joo Lee, MD* Jangsup Moon, MD*

Soon-Tae Lee, MD, PhD

Correspondence to

Dr. S.-T. Lee:

slee@snuh.org

\title{
Teaching NeuroImages: \\ Late-onset Alexander disease
}

Figure $1 \quad$ Brain and spine MRI
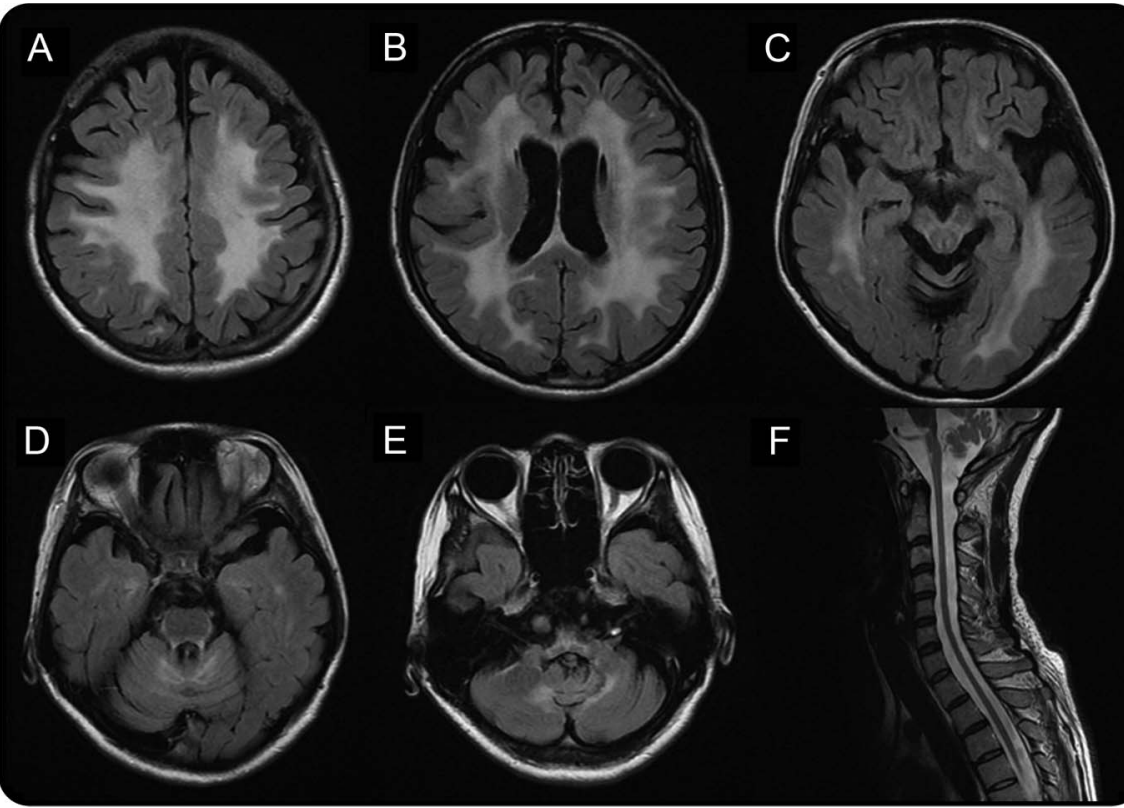

E

F
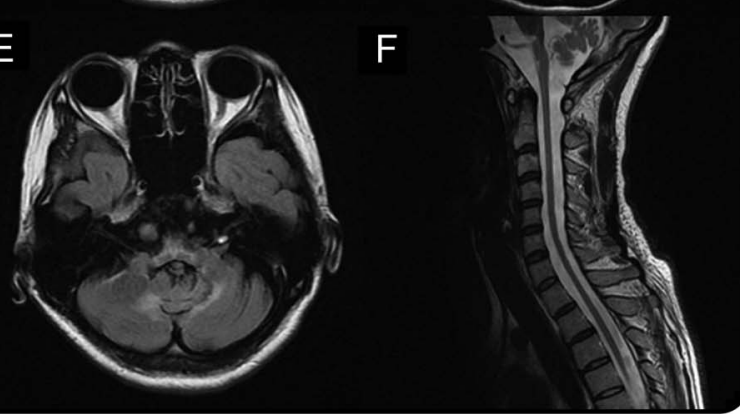

Fluid-attenuated inversion recovery images show diffuse hyperintensities involving periventricular and subcortical white matter (A-C). Pial signal changes around pons (D) and medulla (E) as well as diffuse atrophies of spinal cord (F) are diagnostic clues.

A 38-year-old woman presented with an 8-year history of progressive dysarthria, gait disturbance, and hyperreflexia. MRI revealed leukodystrophy involving brainstem with pial signal changes and spinal cord atrophy (figure 1). Brain biopsy showed Rosenthal fibers (figure 2). She had a de novo mutation of the glial fibrillary acidic protein (GFAP) gene (c.799G $>$ C causing p.Ala267Pro)

Alexander disease is caused by gain-of-function mutation of the GFAP gene. GFAP is an intermediate filament, and mutations result in astrocytic accumulation of eosinophilic inclusions known as Rosenthal fibers. ${ }^{1}$ Late-onset patients show brainstem features (ataxia, dysphagia, dysphonia, and palatal myoclonus) with hindbrainpredominant leukodystrophy and spinal cord atrophy. ${ }^{1,2}$

\section{AUTHOR CONTRIBUTIONS}

Drs. Keon-Joo Lee and Jangsup Moon: drafting the manuscript. Drs. Keon-Joo Lee, Jangsup Moon, and Soon-Tae Lee: study concept, design, and chart review. Dr. Soon-Tae Lee: critical revision of the manuscript and funding support.

\section{STUDY FUNDING}

Supported by a grant (A121911) of the Korean Health Technology R\&D Project, Ministry of Health \& Welfare, Republic of Korea.

\section{DISCLOSURE}

The authors report no disclosures relevant to the manuscript. Go to Neurology.org for full disclosures.

\section{REFERENCES}

1. Messing A, Brenner $M$, Feany $M B$, Nedergaard $M$, Goldman JE. Alexander disease. J Neurosci 2012;32:5017-5023.

2. Graff-Radford J, Schwartz K, Gavrilova RH, et al. Neuroimaging and clinical features in type II (late-onset) Alexander disease. Neurology 2014;82:49-56.
Download teaching slides: Neurology.org
*These authors contributed equally to this work.

From the Department of Neurology, Seoul National University Hospital, South Korea. 
Figure 2 Rosenthal fibers

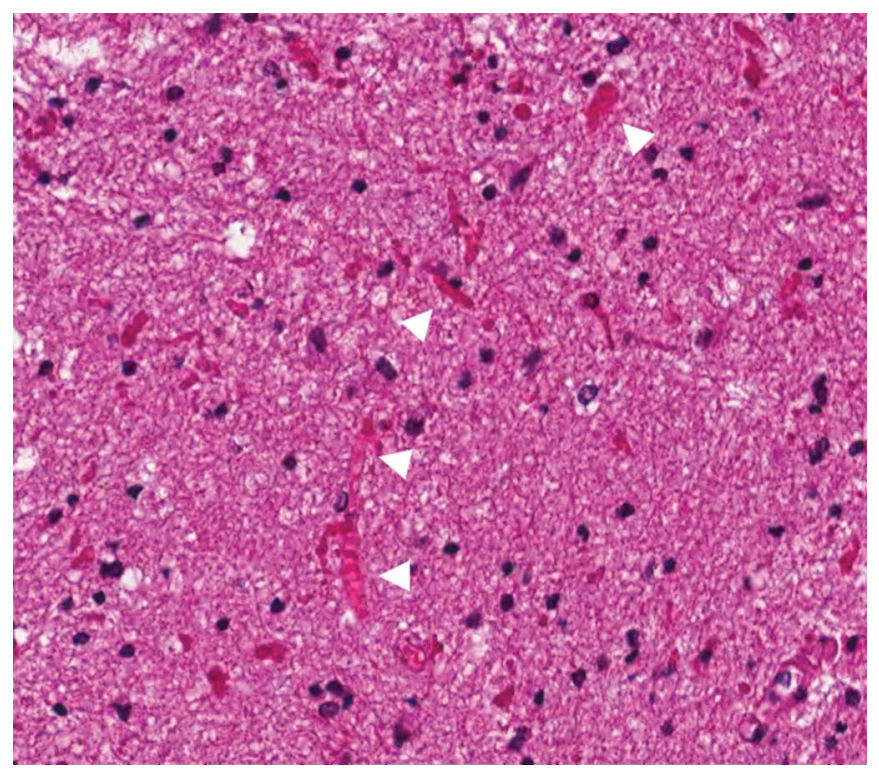

Hematoxylin \& eosin staining of the white matter biopsy showed typical morphology of Rosenthal fibers (arrowheads). Rosenthal fibers are beaded, elongated, or corkscrew-shaped intracytoplasmic inclusions that represent accumulation of intermediate filament. Rosenthal fibers are seen in neoplasms (such as pilocytic astrocytomas), Alexander disease, and reactive tissues with gliosis. 


\title{
Neurology
}

\author{
Teaching NeuroImages: Late-onset Alexander disease \\ Keon-Joo Lee, Jangsup Moon and Soon-Tae Lee \\ Neurology 2014;83;e197-e198 \\ DOI 10.1212/WNL.0000000000001032
}

This information is current as of November 24, 2014

\begin{tabular}{|c|c|}
\hline $\begin{array}{l}\text { Updated Information \& } \\
\text { Services }\end{array}$ & $\begin{array}{l}\text { including high resolution figures, can be found at: } \\
\text { http://n.neurology.org/content/83/22/e197.full }\end{array}$ \\
\hline Supplementary Material & $\begin{array}{l}\text { Supplementary material can be found at: } \\
\text { http://n.neurology.org/content/suppl/2014/11/23/WNL. } 000000000000 \\
\text { 032.DC1 }\end{array}$ \\
\hline References & $\begin{array}{l}\text { This article cites } 2 \text { articles, } 2 \text { of which you can access for free at: } \\
\text { http://n.neurology.org/content/83/22/e197.full\#ref-list-1 }\end{array}$ \\
\hline Subspecialty Collections & $\begin{array}{l}\text { This article, along with others on similar topics, appears in the } \\
\text { following collection(s): } \\
\text { All Genetics } \\
\text { http://n.neurology.org/cgi/collection/all_genetics } \\
\text { MRI } \\
\text { http://n.neurology.org/cgi/collection/mri }\end{array}$ \\
\hline Permissions \& Licensing & $\begin{array}{l}\text { Information about reproducing this article in parts (figures,tables) or in } \\
\text { its entirety can be found online at: } \\
\text { http://www.neurology.org/about/about_the_journal\#permissions }\end{array}$ \\
\hline Reprints & $\begin{array}{l}\text { Information about ordering reprints can be found online: } \\
\text { http://n.neurology.org/subscribers/advertise }\end{array}$ \\
\hline
\end{tabular}

Neurology ${ }^{\circledR}$ is the official journal of the American Academy of Neurology. Published continuously since 1951, it is now a weekly with 48 issues per year. Copyright @ 2014 American Academy of Neurology. All rights reserved. Print ISSN: 0028-3878. Online ISSN: 1526-632X.

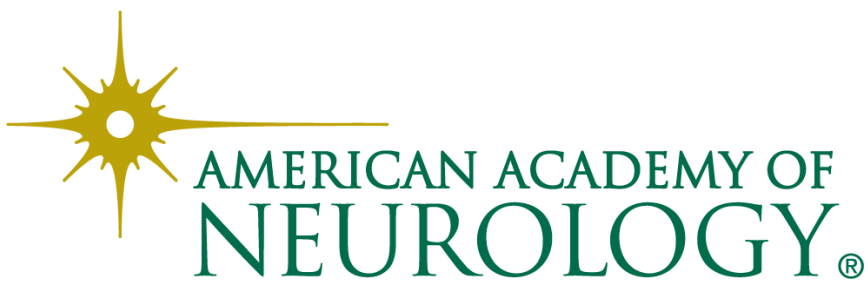

